\title{
IMMUNOHISTOCHEMISTRY OF THE PROGRESSIVE AND REGRESSIVE STAGES OF BOVINE PAPILLOMATOSIS
}

\author{
O. EMHMAD ABDOUSLAM, M. LEVKUT, M. LEVKUTOVÁ, V. REVAJOVÁ, R. ONDREJKA, Z. BENÍSEK \\ Department of Pathological Anatomy, University of Veterinary Medicine, Košice, Slovak Republic
}

Received June 20, 1997

Accepted January 15, 1998

\begin{abstract}
Emhmad Abdouslam O., M. Levkut, M. Levkutová, V. Revajová, R. Ondrejka, Benísek Z.: Immunohistochemistry of the Progressive and Regressive Stages of Bovine Papillomatosis. Acta vet. Brno 1997. 66: 245-248.

The progressive and regressive stages of fibropapilloma in their unusual papillomatous formation in calves are described. Papillated hyperplasia of the epidermis and high mitotic activity in stratum basale characterized the progressive stage. The regressive stage (120 days later) showed infiltration of dermal papillary layer by mononuclear cells (CD3+ cells and macrophages), a thin stratum spinosum without long rete ridges, and massive hyalinization of collagen in the dermis. Several basal cells in the mitotic cycle were immunohistochemically positive for papillomavirus. Inmunohistochemically, papillomavirus was demonstrated in these lesions with the higher numbers of virus positive cells in the progressive stage. Some cells in the stratum spinosum showed both cytoplasmic- and nuclear-staining for the virus, which implies the budding of the virion into the cytoplasm in these layers.
\end{abstract}

Bovine papillomatosis, immunohistochemistry, CD3 lymphocytes

Papillomatosis of papilloma-viral aetiology is a benign epithelial neoplasm with (fibropapilloma) or without (papilloma) connective tissue proliferation. Six different types of bovine papilloma virus have been identified as BPV-1 - BPV-6 (Jarret et al. 1984) and classified into subgroups A and B. Subgroup A viruses cause skin fibropapillomas subgroup $B$ viruses cause true epithelial papillomas.

BPV-2 infects traumatized skin and lasts about a year including an initial month of latency and a final 2 months of tumour rejection. Tumour development can be divided into the following four stages (Campo 1995): fibroma with active proliferation of dermal fibroblasts, fibroma with acanthosis, true fibropapilloma, and tumour regression. Tumour regression is probably mediated via cellular immunity because humoral immunity is not effective in initiating tumour regression (Jablonská 1982).

The aim of this paper is to describe the progressive and regressive stages of bovine papillomatosis in its unusual papillomatous formation recorded in the Spiš region (Slovak Republic). In addition, the study deals with the reaction of immunocompetent cells in infected tissue and the participation of $\mathrm{CD} 3$ cells in tissue reaction.

\section{Materials and Methods}

Animals

Skin papillomas naturally developed in 5 young calves ( $1-2$ years old) were included into this study. Samples of fibropapilloma were excised twice in the span of $120 \mathrm{~d}$ of growth.

Processing of histological material

The samples were processed using a standard procedure i.e. fixed in $10 \%$ neutral formalin. and embedded in paraftin. Sections of a thickness of 5-6 $\mu \mathrm{m}$ were stained with haematoxylin - eosin.

I m munohistochemistry

Immunohistochemical reactions were carried out on paraffin sections by means of the biotin - streptavidin amplified peroxidase detection (B-SA) system (Biogenex. San Ramon, CA, USA). The antibodies used are 
Table 1

Details of primary antibodies used

\begin{tabular}{|l|c|c|c|c|}
\hline $\begin{array}{l}\text { Specific } \\
\text { antibodies used }\end{array}$ & $\begin{array}{c}\text { Antibody } \\
\text { pre-treatment }\end{array}$ & Type & Dilution & Source \\
\hline $\begin{array}{l}\text { CD3 } \\
\text { Papillomavirus }\end{array}$ & $\begin{array}{c}\text { Digested } \\
\text { Undigested }\end{array}$ & $\begin{array}{l}\text { Rabbit anti-human } \\
\text { Rabbit anti-bovine }\end{array}$ & $\begin{array}{l}1 \text { in } 300 \\
1 \text { in } 600\end{array}$ & $\begin{array}{c}\text { Dakopatts } \\
\text { Dakopatts }\end{array}$ \\
\hline
\end{tabular}

summarized in Table 1. Briefly, the sections were incubated for $18 \mathrm{~h}$ at $40^{\circ} \mathrm{C}$ with a primary antibody diluted in phosphate buffered saline $(\mathrm{pH}$ 7.6). Monoclonal antibody to irrelevant epitopes was used as a control. Immunological reactions were revealed by diamino-benzidine (DAB). Sections were then counter-stained with Mayer's haematoxylin.

\section{Results}

Tumours were localized on the head, neck, dewlap. and occasionally on the legs and teats. Tumours in the progressive stage formed pedunculated or broad-based formations of different size sharply limited from the non-infected skin tissue and strongly attached to deep structures of the skin. Histologically, this exophytic mass was composed of hyperplasia of stratum spinosum (acanthosis) and was accompanied by vacuolation of cells in this layer (Plate V., Fig 1). Many cells of acanthotic stratum spinosum showed apoptosis that was characterized by shrinkage of the cytoplasm and nuclear pyknosis without inflammatory reaction. Mitotic activity was high in the basal layer. In the hyperplastic stratum spinosum keratohyaline granules were observed. Rete ridge formations were distinct. but dermal proliferation predominated. Immunohistochemically, cells contained viruses were seen in all layers of the epidermis (Fig 2) and also some fibroblasts of the dermis were positive to virus. Pyknosis of cells was often connected with positivity of cells for virus in the stratum spinosum. Some of the mitotic cells in the basal layer also showed positivity to virus. Only occasionally mononuclear cells (CD3+ cells and macrophages) were seen in the perivascular part of the dermal papillary layer in this period.

In the regressive stage ( $120 \mathrm{~d}$ later) the tumours were broad-based shrivelled, easily detached from deep structures of skin tissue. The stratum spinosum was thinner without long rete ridges and with persistence of the thick stratum corneum (Plate VI., Fig 3). Vacuolation of cells in the stratum spinosum was only occasionally observed. Virus positive cells were rarely observed in the epidermis and dermis. Macrophages and lymphocytes, mainly CD3+, infiltrated the dermis perivascularly (Fig 4). In the dermal part of warts, massive necrosis of collagen was distinctly seen. Fibrocytes were scarce and their nuclei were often pyknotic.

\section{Discussion}

The extent and multiplicity of lesions including the enormous mass of papillomatous

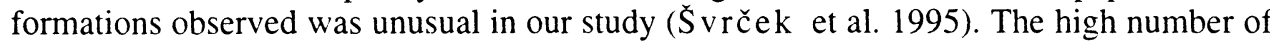
affected animals can be related to chemical or immunomodulating factors, which can activate the latent virus (Campo 1995). There is evidence of latent infection by papillomavirus. The warts can be developed in both immunosuppressed and immunocompetent animals (Ca m po 1994). Immunosuppression is a very important factor in papillomavirus-associated carcinogenesis in cattle (Campo 1987).

By means of antibody against group specific bovine papillomavirus used in our experiment the type of virus can not be determined. Localization of tumours and their histological structure suggests the induction of tumour by BPV-2. The regression of tumours observed in our study also confirmed our assumption consider the virus which induced the 
infection of calves as BPV-2. Papillomaviruses have remarkable target-site specificity, in that skin-infecting viruses do not productively infect the mucosa, and vice versa ( $\mathrm{Campo}$ 1995).

Progressive changes followed by regressive ones in the fibropapillomas indicate the immuno-competence of infected animals. It is known that fibropapillomas are normally rejected by the host cell-mediated immune response. Macrophages and lymphocytes (mainly CD3+) were seen 4 months later in the dermis. For determination of CD3 lymphocytes, a polyclonal anti-CD3 antibody was chosen for its cross-reaction with bovine lymphocytes (Kolodzieyski and Revajová 1996) and for its commercial availability. It is known that the CD3 component is the part of the T-cell receptor (TCR) complex and that it expresses CD4 and/or CD8 positive lymphocytes (Clevers et al. 1988). Infected animals showed significantly lower ratio of $\mathrm{CD} 4$ to $\mathrm{CD} 8$ cells $(1.47 ; \mathrm{P}<0.05)$ compared with ratio of CD4 to CD8 lymphocytes (2.32) in peripheral blood of non-infected animals (Levkutová et al. unpublished data). This suggests depressed lymphocyte reactivity as a result of excessive suppressor activity (Tizard 1992).

The higher number of infected cells in the epidermis in the progressive stage compared with the regressive stage shows the gradual suppression of virus production. Suppression of papillomavirus production is an accompanying feature of tumour regression (Jarret et al. 1991). Death of cells showing positivity to virus often observed in the stratum spinosum seems to be connected to the replication of the virus in the nucleus. As Ols o n (1990) describes, the virus infects the basal cells of the epidermis, causing their to degeneration while other cells are stimulated to excessive growth and wart formation. In our study some of the cells in the mitotic cycle were virus-positive. This supposes that the virus can be spread also by the replication of cells. The high mitotic activity of basale cells in our cases is expression of the excessive growth in the fibropapilloma stage. Massive necrosis of collagen in the subepidermal layer of warts in the regressive stage may be in relation to rejection of tumour tissue. Electron microscopic analysis reveals virions in crystalline array in nuclei of degenerated cells in the keratinizing layer (Jelínek and Jirásek 1979; Lancaster and Olson 1982). Multiplication of the virus particles caused degeneration of the cells and virions may completely replace the nuclear material when the cell reaches the surface of the fibropapilloma (Ols on 1990). Shrinking of the cell and the pyknosis of the nucleus in the stratum spinosum is typical for apoptosis (A rai et al. 1996).

The study confirms that animals are able to reject fibropapilloma caused by some types of BPV. The study indicates that mononuclear cells infiltrated in the dermis of the fibropapilloma in regressive stage are mainly $\mathrm{CD} 3+$ and macrophages. Additional experimental studies could define subpopulations of lymphocytes included in the immunology of tumour rejection.

\section{References}

ARAI, S., KOWADA, T., TAKEHANA, K., MIYOSHI, K., NAKANISHI, Y. H., HAYASHI, M. 1996: Apoptosis in the chicken bursa of Fabricius induced by X-irradiation. J. Vet. Med. Sci. 58: $1001-1006$

BARTHOLD. S. W., OLSON, C. 1974: Fibroma regression in relation to antibody and challenge immunity to bovine papillomavirus. Cancer Res. 24: 2426-2431

CAMPO, M. S. 1987: Papillomas and cancer in cattle. Cancer Surv. 6: 39-54

CAMPO, M. S., JARRET, W. F., O`NEIL, B. W.. BARRON, R. J. 1994: Latent papillomavirus infection in cattle. Res. Vet. Sci. 56: 151-157

CAMPO. M. S. 1995: Infection by bovine papillomavirus and prospects for vaccination. Trends Microbiol. 3: $92-97$ CLEVERS, H., ALARCON, B., WILEMAN. T., TERHORST. C. 1988: The T-cell receptor/CD3 complex: A dynamic protein ensemble. Annu. Rev. Immunol. 6: 629-662

JABLONSKÁ, S., ORTH, G., LUTZNER, M. A. 1982: Immunopathology of papillomavirus - induced tumours in different tissues. Springer Semin. Immunopathol. 5: 33-62 
JARRETT, W. F. H., CAMPO, M. S., O’NEIL, B. W., LAIRD, H. M., COGGINS, L. W. 1984: A novel bovine papillomatosis (BPV-6) causing true epithelial papillomas of the mammary gland skin: A member of a proposed new BPV subgroup. Virology 136: 255-264

JARRETT, W. F. H., SMITH, K. T., O'NEIL, B. W., GAUKROKER, J. M., CHANDRACHUD, L. M., GRINDLAY, G. J., MCGARVIE, G. M., CAMPO, M. S. 1991: Studies on vaccination against papillomaviruses: Prophylactic and therapeutic vaccination with recombinant structural proteins. Virology 184: 33-42

JELINEK, F., JIRÁSEK, A. 1979: Papovavirová papilomatóza beaglủ. Ćs. patologie 15: 163-167

KOLODZIEYSKI, L., REVAJOVÁ, V. 1996: Distribution of CD3 lymphocytes in the lymph nodes of cows infected by BLV. Folia Veterinaria 40: 61-64

LANCASTER, W. D., OLSON, C. 1982: Animal papillomaviruses. Microbiol. Rev. 46: 191-207

OLSON, R. O., OLSON, C., EASTERDAY, B. C. 1982: Papillomatosis of the bovine teat. Am. J. Vet. Res. 43: 2250-2252

OLSON, C. 1990: Papillomaviruses. In: Dinter, Z., Morein, B. (ed.) Virus Infections of Ruminants. Elsevier Sci. Publ., Amsterdam, pp. 189-210

ŠVRČEK, Š., LEŠNIK, F., MARÁČEK, I., JANDA, J., ONDREJKA, R., KONRÁD, V., LEVKUT, M., SULIOVÁ, J., BENÍŠEK, Z., BAJOVÁ, V., BÍREŚ, J., BARTKO, P., PAULÍK, Š., PALKOVIČ, J., KOCHAN, P., NÉMETHOVÁ, K., ZÁVADOVÁ, J., ḊUROVE, A. AND MOJŽIŠOVÁ, J. 1995: Neobvyklá forma výskytu bovinnej papilomatózy na Spiši. Slov. vet. čas. 20: 163-168

TIZARD, I. 1992: Lymphocytes. In: Tizard, I. (ed) Veterinary Immunology: An Introduction. W. B. Saunders Company, Philadelphia, pp. 72-84

Doc. MVDr. Mikulás Levkut, CSc.

Department of Pathological Anatomy

University of Veterinary Medicine

Komenského 73

04181 Košice

Slovak Republic

Phone: 42195 6229924, ext. 416

Fax: 421956323666

E-mail:patanat@uvm.sk 
Plate V.

Abdouslam O. E. et al.: Immunohistochemistry ... pp. 245-248.

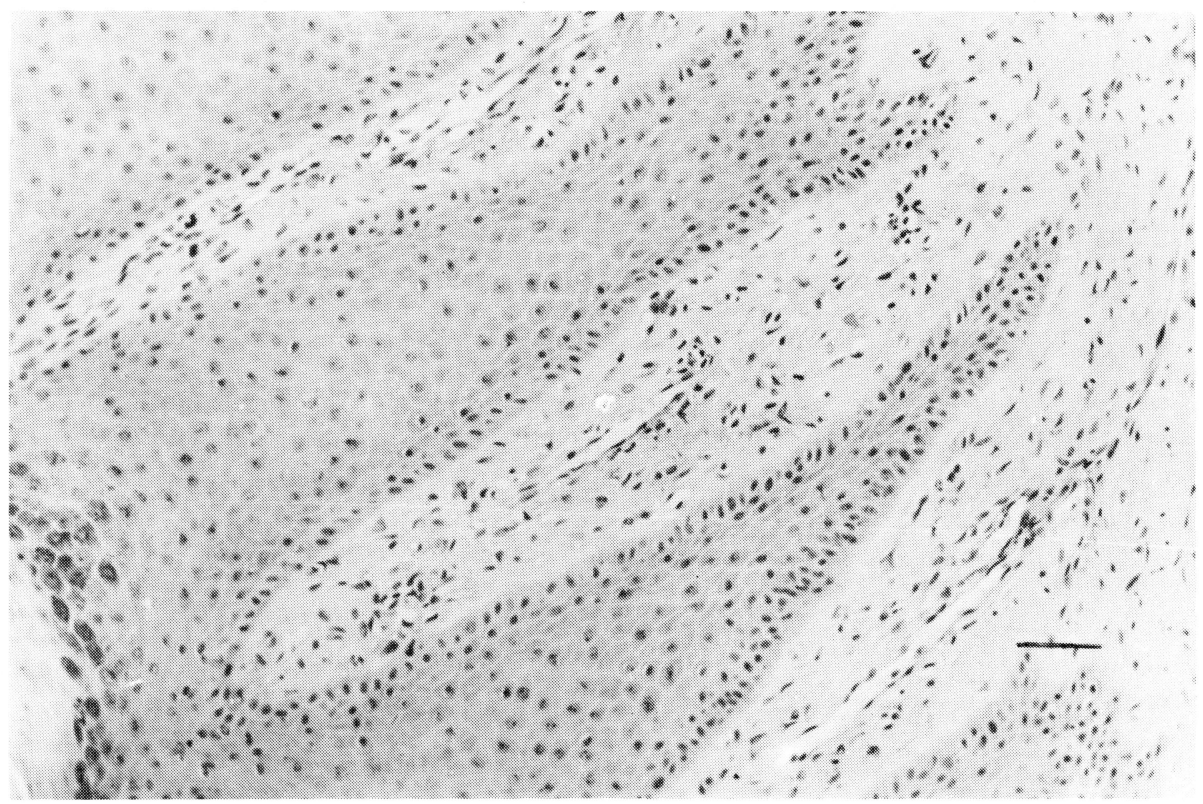

Fig 1: Deep rete ridges in progressive stage of bovine fibropapilloma. $\mathrm{HE} \times 160$

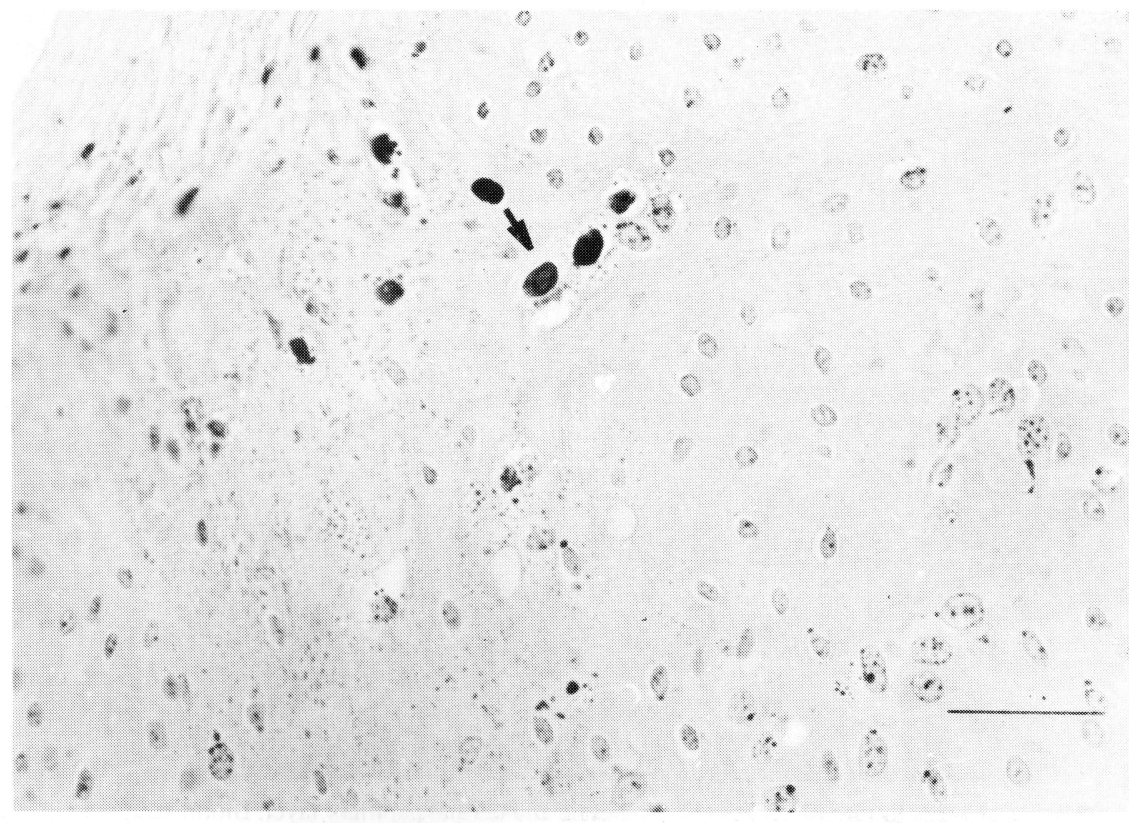

Fig 2: Virus positive cells (arrow) in stratum spinosum of fibropapilloma. Biotin-streptavidin-peroxidase. $\times 320$ 


\section{Plate VI.}

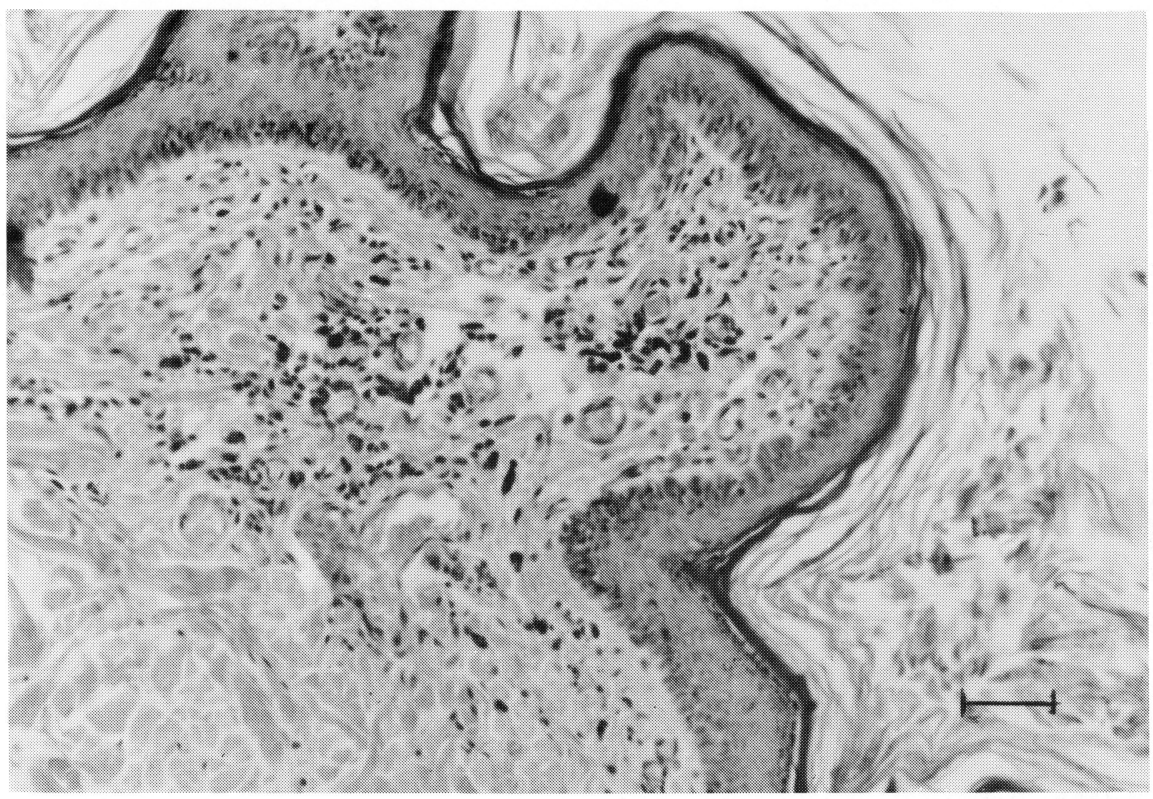

Fig 3: Regressive stage of bovine fibropapilloma. Stratum spinosum without deep rete ridges in regressive stage of bovine fibropapilloma. In the dermal papillary layer, there is mainly perivascular round-cell cellulation. $\mathrm{HE} \times 160$

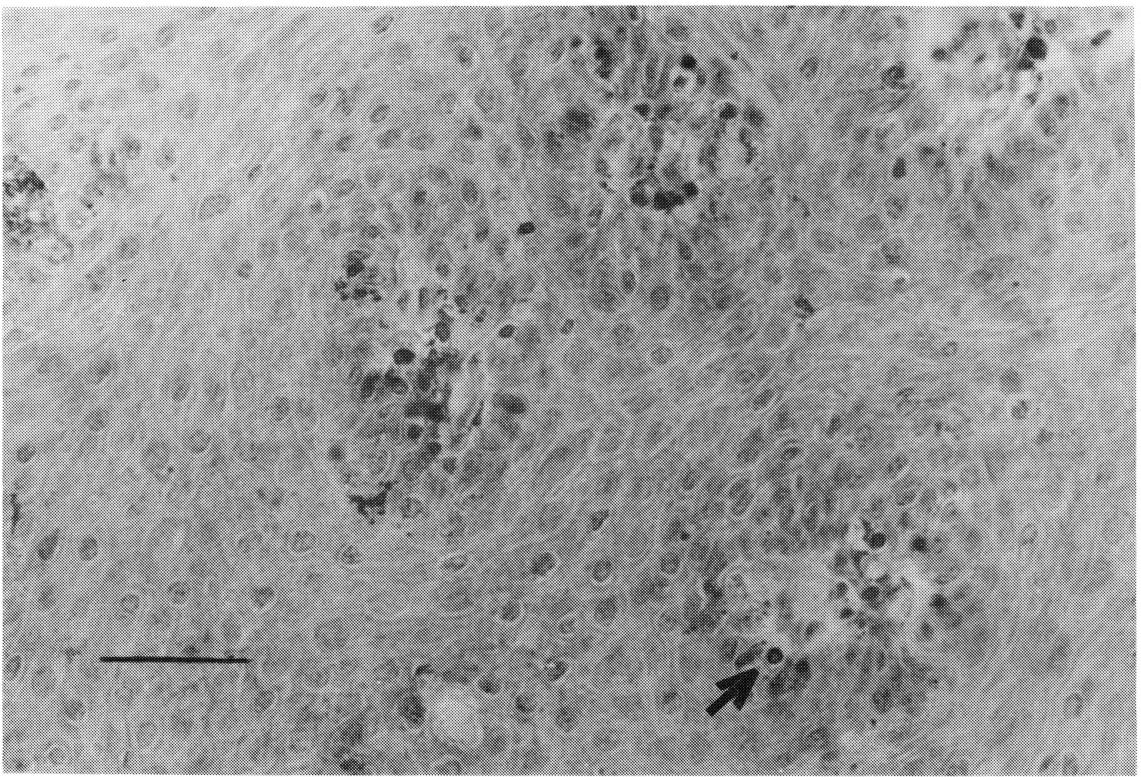

Fig 4: CD3 positive cells (arrow) in the stratum basale and dermal papillary layer. Biotin-streptavidinperoxidase. $\times 320$ 